\title{
EFFECT OF SOME TYPES OF PROTEIN NUTRITION ON THE PRODUCTIVITY OF HONEY BEE VENOM
}

\author{
Esraa A.M.A. Badawy ${ }^{*}$, M.N. El-Bassiony², \\ H.M. Mahfouz ${ }^{2}$ and H.T. Abou El-Enain ${ }^{1}$
}

1. Dept. Beekeeping Res., Res. Inst. Plant Protec., Agric. Res. Cen., Egypt.

2. Dept. Plant Prod., Fac. Environ. Agric. Sci., Arish Univ., Egypt.

\begin{abstract}
Experiments were conducted in the apiary of Honey Bee Research Center. A field experiment was carried out during 2014 and 2015 seasons, at the Experimental Research Station of the Agriculture Research Center, El-Arish, North Sinai, to study the impact of different sources of nutritive protein on honey bee worker venom gland secretion. The aim of this study is to determine the effects of some factors that could increase the productivity of honeybee venom. This investigation discusses improving the production of the venom from honeybee's colonies by using the electrical impulses technique. This study includes several essential factors, such as using different types of nutrition proteins $1: 1 \mathrm{~W}$ : W of honey bee to beer yeast or soya beans or natural pollen grain, respectively. Results indicated that the natural pollen grain is the best because it is mainly provide structural elements of muscles, glands and other tissues.
\end{abstract}

Key words: Honeybee, VCD, Bee Venom, Nutritive proteins, Collection, Sting apparatus, Acid gland, Venom sac.

\section{INTRODUCTION}

Bee venom therapy is a part of apitherapy which utilizes bee venom in the treatment of health conditions. It has been used from an old era to modern end as an alternative therapy to treat several diseases like: Multiple sclerosis, Lyme disease, and Chronic fatigue syndrome. Bee venom has a rich source of enzymes, peptides and biogenic amines and contains at least 18 active components.

The aim of this study is to determine the effects of some factors that could increase the productivity of honeybee venom. (ElBassiony, 2007; El-Shaarawy, 2007) found that using the pollen grain diet treatment gave the best results for bee venom production comparing with the other treatments (free fate milk, dead yeast and sugar solution. Omar (2011) found that when newly emerged honey bee workers were fed on sufficient level of stored bee bread in bee colonies, the total length of acid gland increased with the age and reached to the maximum length at $18^{\text {th }}$ dayold $(13.03 \mathrm{~mm})$. The length of acid gland started to decrease again at $24^{\text {th }}$ day-old.

\section{MATERIALS AND METHODS}

Experiments were conducted in the apiary of Honey Bee Research Center. A field experiment was carried out during 2014 and 2015 at the Experimental Research Station of the Agriculture Research Center,

El-Arish, North Sinai, in order to study some factors which affecting secretion of honey bee worker venom gland such as: the

\footnotetext{
* Corresponding author: Tel.: +201202968118

E-mail address: esraa.badawy@yahoo.com
} 
different types of nutritive protein through two different seasons. The aim of this study is to determine the effects of some factors that could increase the productivity of honeybee venom.

This investigation discusses improving the production of the venom from honeybee's colonies by using the electrical impulses technique. This study includes several essential factors, such as sources of different nutrition proteins as $1: 1 \mathrm{~W}$ : $\mathrm{W}$ of honey bee to beer yeast or soya beans or natural pollen grain, respectively.

Relation between amount collected bee venom from worker venom gland and different types of nutritive protein in honeybee colonies after 10 days from feeding during 2014 and 2015 seasons (spring, summer, fall, winter) respectively.

Twelve honeybee colonies from local hybrid Carniola bees, relatively equal in their strengths were chosen and divided into three groups as follows:

\section{First Group}

Each colony contains 50 grams of bear yeast cake (pollen traps were situated on the entrance of each hive to avoid the presence of pollen grains in it). The bear yeast cake prepared from 1:1 $W: W$ of bear yeast: honey bee.

\section{Second Group}

Each colony contains 50 grams of soybean cake (pollen traps were situated on the entrance of each hive to avoid the presence of pollen grains in it). The soybean cake prepared from $1: 1 \mathrm{~W}: W$ of soybean: honey bee

\section{Third Group}

Each colony contains 50 grams of pollen grain cake. The pollen grain cake prepared from $1: 1 W: W$ of pollen grain: honey bee. Feeding in each group was every 10 days and each group was subdivided into four subgroups, one of them control and the rest of three subgroups fed on the specific type of nutritive protein.

\section{RESULTS AND DISCUSSION}

\section{Relationship Between Some Types Effect of Protein Nutrition and the Amount of Honey Bees Producing After 10 Days from Feeding Operation During 2014 and 2015 Seasons}

Results in Table 1 show the impact of different types of protein nutrition on the amount of bee venom produced after 10 days of feeding operation during spring season. Application of pollen feed had the highest significant $(\mathrm{P} \leq 0.05)$ values 1.661 $\mathrm{mg}$ /colony of dry bee venom which produced from Carniolan hybrid honeybees colonies by using electrical impulses device during 2014 and 2015 seasons.

The result clearly show that the pollen grain feeding the amount of dry bee venom was increased by $73.382 \%$ in first season 2014 and $64.461 \%$ in second season 2015 as compared with that of venom produced from control. These results are in agreement with many authors (Omar, 1994a; Omar 1997; Zakaria and Ammany, 2004). They said that the nutrition has an important effect in venom production and the honeybee workers that fed artificially in cages without giving proteins (pollen) produce less much venom than that fed got protein in the diet.

In the available literature, honey bee workers used protein of pollen mainly to provide structural elements of muscles, glands and other tissues. Under normal conditions, pollen consumption diminishes when the bees are of 8 to 10 days old (Dietz, 1975). The stored pollen areas in excited honey bee colonies by electrical impulses for venom production decreased. 
SINAI Journal of Applied Sciences (ISSN: 2314-6079) Vol. (5) Is. (3), Dec. 2016

Table (1): The relationship between some types of protein nutrition on the amount of honey bees producing after 10 days from feeding during spring of 2014 and 2015 seasons.

\begin{tabular}{|c|c|c|c|c|c|c|c|c|}
\hline \multicolumn{9}{|c|}{ Dry bee venom(mg/colony/20 minutes) } \\
\hline \multicolumn{5}{|c|}{2014} & \multicolumn{4}{|c|}{2015} \\
\hline $\begin{array}{l}\text { Type of } \\
\text { protein } \\
\text { food }\end{array}$ & Min. & Max. & $\begin{array}{c}\text { Mean } \pm \\
\text { S.E. }\end{array}$ & $\begin{array}{l}\text { (\%) Rate of } \\
\text { increment }(+) \\
\text { or Decrement } \\
\text { (-) from } \\
\text { (control) }\end{array}$ & Min. & Max. & $\begin{array}{c}\text { Mean } \pm \\
\text { S.E. }\end{array}$ & $\begin{array}{c}\text { \%Rate of } \\
\text { increment }(+) \\
\text { or Decrement } \\
\text { (-) from } \\
\text { (control) }\end{array}$ \\
\hline Control & 0.533 & 1.530 & $\begin{array}{l}0.958 \mathrm{~b} \\
\pm 0.056\end{array}$ & Control & 0.569 & 0.831 & $\begin{array}{l}0.650 \mathrm{~b} \\
\pm 0.083\end{array}$ & control \\
\hline Pollen & 1.101 & 2.688 & $\begin{array}{l}1.661 \mathrm{a} \\
\pm 0.353\end{array}$ & $-73.382 \%$ & 0.677 & 1.428 & $\begin{array}{l}1.069 \mathrm{a} \\
\pm 0.085\end{array}$ & $-64.461 \%$ \\
\hline Soyabean & 0.618 & 1.218 & $\begin{array}{l}0.960 \mathrm{~b} \\
\pm 0.070\end{array}$ & $-\cdot .208 \%$ & 0.462 & 1.026 & $\begin{array}{l}0.686 \mathrm{~b} \\
\pm 0.083\end{array}$ & $-5.538 \%$ \\
\hline Yeast & 1.047 & 1.252 & $\begin{array}{l}1.121 \mathrm{ab} \\
\pm 0.078\end{array}$ & $-17.014 \%$ & 0.437 & 1.004 & $\begin{array}{l}0.702 \mathrm{~b} \\
\pm 0.134\end{array}$ & $-8 \%$ \\
\hline LSD 5\% & & & 0.609 & & & & 0.2806 & \\
\hline
\end{tabular}

These results can be explained that stressed bees by electrical impulses consumed more protein for developing venom glands (Omar, 1994b). In their study on the efficacy of feeding protein substitutes to honey bee found slightly poorer development of honey bee glands against that fed bee bread. Also, Hanna and Schmidt (2004) reported that the biotic effect of different pollen substitutes was poor in comparison with bee bead stored in honey bee colonies (Szymas and PrzybyI , 1996). The results showed that scarcity bee venom in honey bee colonies during the period extraction reduced venom production by $50.3 \%$ (Omar, 2011).

Results in Table 2 show the effect of some types of protein nutrition on the amount of honey bees producing after 10 days from feeding operation during summer season. The results reflected the same trend of spring where the highest $(\mathrm{P} \leq 0.05)$ dry bee venom was recorded with application of pollen feed which producing from Carniolan hybrid honeybees colonies by using electrical impulses device during 2014 and 2015 in both seasons without significant differences with application of soyabean, yeast and control in both seasons.

Also, the results clearly show that after using pollen grain feeding the amount of dry bee venom increased by $79.322 \%$ in first season of 2014 and $32.735 \%$ in second season of 2015 as compared with that of venom produced from control .This means that the use of pollen in nutrition gave the highest significant $(\mathrm{P} \leq 0.05)$ values 1.184 $\mathrm{mg} /$ colony between treatments of dry bee venom in both seasons. 
Table (2): The relationship between some types of protein nutrition and the amount of honey bees producing after 10 days from feeding during Summer2014 and 2015 seasons.

\begin{tabular}{|c|c|c|c|c|c|c|c|c|}
\hline \multicolumn{9}{|c|}{ Dry bee venom(mg/colony/20 minutes) } \\
\hline \multicolumn{5}{|c|}{2014} & \multicolumn{4}{|c|}{2015} \\
\hline $\begin{array}{c}\text { Type of } \\
\text { protein } \\
\text { food }\end{array}$ & Min. & Max. & $\begin{array}{l}\text { Mean } \pm \\
\text { S.E. }\end{array}$ & $\begin{array}{c}\text { (\%) Rate of } \\
\text { increment }(+) \text { or } \\
\text { Decrement(-) } \\
\text { from (control) } \\
\end{array}$ & Min. & Max. & $\begin{array}{l}\text { Mean } \pm \\
\text { S.E. }\end{array}$ & $\begin{array}{c}(\%) \text { Rate of } \\
\text { increment }(+) \text { or } \\
\text { Decrement }(-) \\
\text { from (control) }\end{array}$ \\
\hline \multirow[t]{2}{*}{ Control } & 0.470 & 0.967 & $0.590 \mathrm{~b}$ & Control & 0.956 & 1.041 & $0.892 \mathrm{~b}$ & Control \\
\hline & & & \pm 0.134 & & & & \pm 0.117 & \\
\hline \multirow[t]{2}{*}{ Pollen } & 0.580 & 1.618 & $1.058 \mathrm{a}$ & $-79.322 \%$ & 1.127 & 1.377 & $1.184 \mathrm{a}$ & $-32.735 \%$ \\
\hline & & & \pm 0.066 & & & & \pm 0.056 & \\
\hline \multirow[t]{2}{*}{ Soyabean } & 0.424 & 1.015 & $0.703 \mathrm{ab}$ & $-19.152 \%$ & 0.857 & 1.113 & $0.853 \mathrm{~b}$ & $+4.572 \%$ \\
\hline & & & \pm 0.160 & & & & \pm 0.116 & \\
\hline \multirow[t]{2}{*}{ Yeast } & 0.128 & 0.916 & $0.532 \mathrm{~b}$ & $+9.830 \%$ & 0.942 & 1.479 & $1.098 \mathrm{~b}$ & $-23.094 \%$ \\
\hline & & & \pm 0.124 & & & & \pm 0.149 & \\
\hline LSD 5\% & & & 0.3722 & & & & 0.3398 & \\
\hline
\end{tabular}

According to (El-Shaarawyet al., 2007) located that the best result was with the pollen grains where in it gives the highest bee venom quantity followed with the powder milk then the medical yeast and the sugar solution was at last.

Results in Table 3 show the effect of the relationship between some types of protein nutrition and the amount of honey bees producing after 10 days from feeding operation during fall season. The results reflected the same trend of summer where the highest $(\mathrm{P} \leq 0.05)$ of dry bee venom was recorded with application of pollen feed which producing from Carniolan hybrid honeybees colonies by using electrical impulses device during 2014 and 2015 seasons without o significant differences with application of soyabean, yeast and control in both seasons.

Also, the results clearly show that after using pollen grain feeding, the amount of dry bee venom increased by $40.220 \%$ in first season (2014) and 76.058\% in second season (2015) as compared with that of venom produced from control. This means that the use of pollen in nutrition given the highest significant $(\mathrm{P} \leq 0.05)$ values 0.956 $\mathrm{mg} /$ colony between treatments of dry bee venom in both seasons.

Hayes (1984) recommended that the soybean flour and yeast added to candy as a food to be given to honey bee colonies in the spring. Also, Cook and Wilkinson (1986) indicated that the pollen substitute diets produce inconsistent results. Szymas and Przybyl (1996) investigated how feeding with some pollen substitutes affected different tissues of honey bee and they found that the development of some organs were similar to that of bees that were fed bee bread. Results in Table 4 show that the effect of the relationship between some types of protein nutrition and the amount of honey bees producing after 10 days from feeding operation during summer season. 
SINAI Journal of Applied Sciences (ISSN: 2314-6079) Vol. (5) Is. (3), Dec. 2016

Table (3): The relationship between some types of protein nutrition and the amount of honey bees producing after 10 day from feeding during fall 2014 and 2015 seasons

\begin{tabular}{|c|c|c|c|c|c|c|c|c|}
\hline \multicolumn{9}{|c|}{ Dry bee venom(mg/colony/20 minutes) } \\
\hline \multicolumn{5}{|c|}{2014} & \multicolumn{4}{|c|}{2015} \\
\hline $\begin{array}{l}\text { Type of } \\
\text { portentous } \\
\text { food }\end{array}$ & Min. & Max. & $\begin{array}{c}\text { Mean } \pm \\
\text { S.E. }\end{array}$ & $\begin{array}{c}(\%) \text { Rate of } \\
\text { increment }(+) \text { or } \\
\text { Decrement }(-) \\
\text { from (control) }\end{array}$ & Min. & Max. & $\begin{array}{l}\text { Mean } \pm \\
\text { S.E. }\end{array}$ & $\begin{array}{c}(\%) \text { Rate of } \\
\text { increment }(+) \text { or } \\
\text { Decrement }(-) \\
\text { from (control) }\end{array}$ \\
\hline Control & 0.136 & 0.655 & $\begin{array}{c}0.363 \mathrm{~b} \\
\pm 0.012\end{array}$ & Control & 0.424 & 0.700 & $\begin{array}{l}0.543 \mathrm{~b} \\
\pm 0.055\end{array}$ & Control \\
\hline Pollen & 0.183 & 0.947 & $\begin{array}{l}0.709 \mathrm{a} \\
\pm 0.067\end{array}$ & $-40.220 \%$ & 0.188 & 1.615 & $\begin{array}{l}0.956 \mathrm{a} \\
\pm 0.026\end{array}$ & $-76.058 \%$ \\
\hline Soyabean & 0.139 & 0.701 & $\begin{array}{c}0.378 \mathrm{ab} \\
\pm 0.039\end{array}$ & $-4.132 \%$ & 0.185 & 1.109 & $\begin{array}{l}0.598 b \\
\pm 0.033\end{array}$ & $-10.128 \%$ \\
\hline Yeast & 0.092 & 0.593 & $\begin{array}{l}0.318 b \\
\pm 0.037\end{array}$ & $+12.396 \%$ & 0.040 & 0.495 & $\begin{array}{l}0.253 \mathrm{c} \\
\pm 0.107\end{array}$ & $+53.406 \%$ \\
\hline LSD 5\% & & & 0.1352 & & & & 0.1982 & \\
\hline
\end{tabular}

Table (4): The relationship between some types of protein nutrition and the amount of honey bees producing after 10 days from feeding during winter 2014/2015 seasons.

\begin{tabular}{cccccccccc}
\hline \multicolumn{7}{c}{ Dry bee venom (mg/colony/20 minutes) } \\
\hline $\begin{array}{c}\text { Type of } \\
\text { portentous } \\
\text { food }\end{array}$ & Min. & Max. & $\begin{array}{c}\text { Mean } \pm \\
\text { S.E. }\end{array}$ & $\begin{array}{c}\text { (\%) Rate of } \\
\text { increment (+) or } \\
\text { Decrement (-) } \\
\text { from (control) }\end{array}$ & Min. & Max. & $\begin{array}{c}\text { Mean } \pm \\
\text { S.E. }\end{array}$ & $\begin{array}{c}\text { (\%) Rate of } \\
\text { increment (+) or } \\
\text { Decrement (-) } \\
\text { from (control) }\end{array}$ \\
\hline Control & 0.128 & 0.383 & $0.222 \mathrm{a}$ & Control & 0.074 & 0.332 & $0.186 \mathrm{ab}$ & Control \\
& & & \pm 0.098 & & & & \pm 0.062 & \\
Pollen & 0.198 & 0.383 & $0.341 \mathrm{a}$ & $-53.603 \%$ & 0.076 & 0.971 & $0.384 \mathrm{a}$ & $-213.978 \%$ \\
& & & \pm 0.163 & & & \pm 0.227 & \\
Soyabean & 0.001 & 0.593 & $0.253 \mathrm{a}$ & $-13.963 \%$ & 0.062 & 0.425 & $0.204 \mathrm{ab}$ & $-9.677 \%$ \\
& & & \pm 0.113 & & & \pm 0.139 & \\
Yeast & 0.017 & 0.418 & $0.187 \mathrm{a}$ & $+15.765 \%$ & 0.022 & 0.164 & $0.081 \mathrm{~b}$ & $+56.451 \%$ \\
& & & \pm 0.072 & & & & \pm 0.026 & \\
LSD 5\% & & & 0.3807 & & & 0.4483 & \\
\hline
\end{tabular}


Results indicated that no significant different between treatment was found in first season 2014 but in second season 2015 , the results reflected the same trend of fall where the highest $(\mathrm{P} \leq 0.05)$ of dry bee venom was recorded with application of pollen feed which producing from Carniolan hybrid honeybees colonies by using electrical impulses device during $20 \mathrm{~min}$ without no significant differences with application of soyabean, yeast and control.

Also, the results clearly show that after using pollen grain feeding the amount of dry bee venom increased by $53.603 \%$ in first season (2014) and $213.978 \%$ in second season (2015) as compared with that of venom produced from control. This means that the use of pollen in nutrition gaven the highest significant $(\mathrm{P} \leq 0.05)$ values 0.584 $\mathrm{mg} /$ colony between treatments of dry bee venom in both seasons.

\section{REFERENCES}

Cook, V.A. and Wilkinson, P.H. (1986). Pollen feeding boosts brood in colonies. Brit Bee J., 114 (1190): 223-226.

Dietz, A.C. (1975). Nutrition of the adult honey bee. In "The Hive and the Honey Bee". Dadant and Sons, Inc. Hamilton, 111: 125-165.

El-Bassiony, A.M. (2007). Monitoring the reproductive individual in the oriental hornet Vespa orientalis. Arab Univ. J. Sci., 15 (2): 459-511.

El-Shaarawy, K.M.O (2007). Studies on certain factors affecting the honey bee venom collection, it's some chemical and antibacterial properties. M.Sc. Thesis, Fac. Agric., Cairo Univ., Egypt.

El-shaarawy, K.O.; Zakaria, M.E.; AzzaTaufik, A. and El-Shemy A.A.M.
(2007). Effect of different bee venom collection periods using electrical shock device on some venom characteristics and honey bee colonies activities. J. Agric. Sci., Mansoura Univ., 32 (6): 4769 - 4775.

Hanna, A. and Schmidt, O. (2004). Effect of phagostimulants in artificial diets on honey bee feeding behavior. South Western Entomol., 29:253-261.

Hayes, J.V. (1984). Supplemental feeding of honey bees. Ame. Bee J., 1:35-37.

Omar, F.M.O. (2011). Some factors affecting acid glands and honey bee venom productivity. M.Sc. Thesis, Assiut Univ., J. Agric. Sci., 89.

Omar, M.O.M. (1994a). New device to extract venom by electrical impulses from honey bee colonies. Assiut J. Agric. Sci., 25: 113-126.

Omar, M.O.M. (1997). Factors affecting defence behavior and venom collection from honey bee colonies by electrical impulses. Proc. $7^{\text {th }}$ Nat. Conf. of Pest. $\mathscr{X}$ Dis. of Vegetables $æ$ Fruits Egypt, 236241.

Omar, M.O.M. (1994b). Some factors affecting bee venom extraction from honey bee colonies. Assiut J. Agric. Sci., 25: 139-148.

Szymas, B. and Przyby, A.I. (1996). Physiological condition of worker bees Apis mellifera L. after consumption of pollen substitute. Pszczaln. Zesz. Nauk. 40 (2): 109-117.

Zakaria, M.E. and Amany, M.Z. (2004). Protein elecrophoretic changes of haemolymph and venom of honey bee workers (Apismelliffera) L. fed on different protein diets., Bull. Ent. Soc. Egypt, 30:43-55. 


$$
\begin{aligned}
& \text { الملخص العربي } \\
& \text { دراسة تأثير بعض أنواع التفذية البروتينية على إنتاجية سم التحل }
\end{aligned}
$$

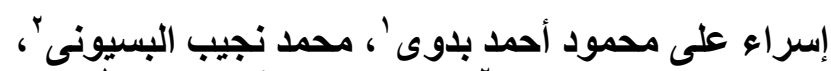

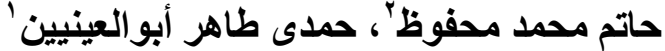

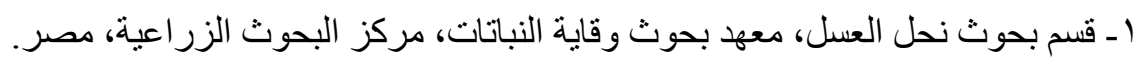

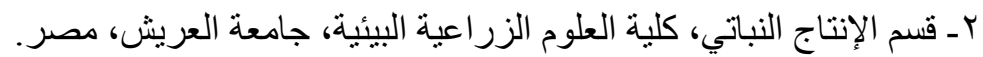

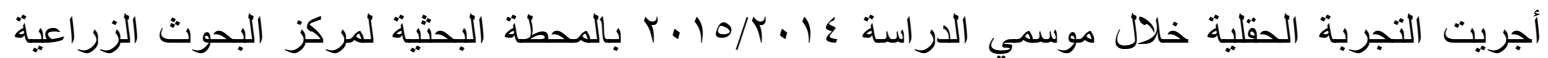

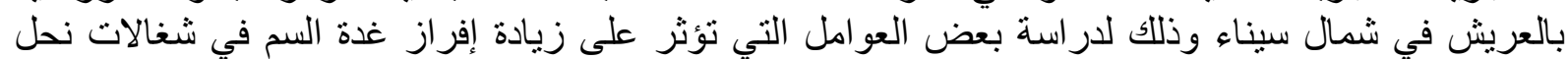

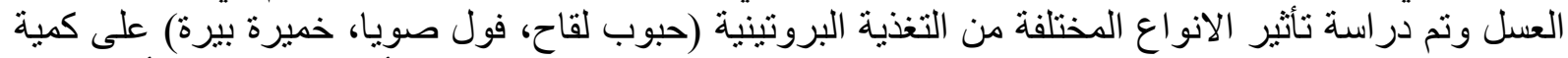

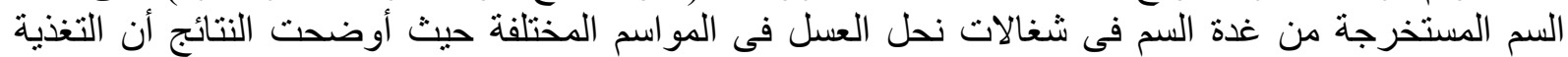

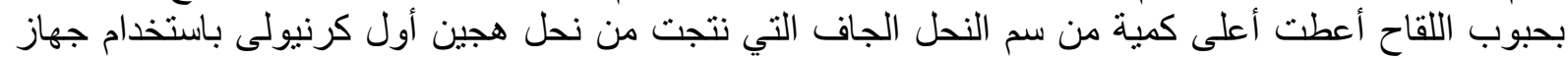

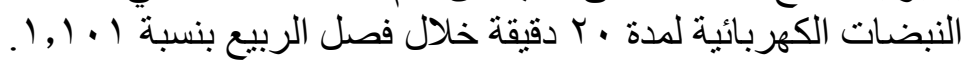

الكلمات الاسترشادية: نحل العسل، جهاز تجميع السم، سم النحل، التغذية البروتينية، حبوب اللقاح، الغدة الحمضية، التهابة الأنشطة

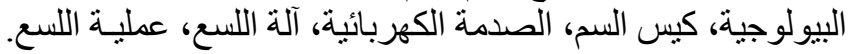


Badawy, et al. 